\title{
Islamic Education in Thailand Pattani Muslim Minority: What are the Institutional Continuity and Change?
}

\author{
Ismail Suardi Wekke ${ }^{12 *}$, Siddin ${ }^{1}$, Sukree Langputeh ${ }^{3}$ \\ ${ }^{1}$ Postgraduate Program, Sekolah Tinggi Agama Islam Negeri (STAIN) Sorong, Indonesia \\ ${ }^{2}$ Academy of Islamic Studies and Arabic Language, University College of Yayasan Pahang, Malaysia \\ ${ }^{3}$ Faculty of Social Science and Humanities, Fatoni University, Thailand
}

\section{Article History:}

Received: February $19^{\text {th }}, 2019$

Revised: May $17^{\text {th }}, 2019$

Accepted: June $15^{\text {th }}, 2019$

Published: June $28^{\text {th }}, 2019$

\section{Keywords:}

Institutions,

Islamic Education,

Muslim Minority

\footnotetext{
*Correspondence Address:

ismail@stain-sorong.ac.id
}

\begin{abstract}
National aspiration in different ways effects to the community response through their condition. This situation reflects the dynamics of interest in diverse direction. Therefore, this article will identify the development of Muslim minority in Pattani, Thailand. A qualitative approach was applied to conducting research. In-depth interview and non-participant observation was an instrument to collect data. Data triangulation was conducted through twice focus group discussions in a different university. This article discusses the portrait of Islamic education in Pattani of Thailand. They face dynamic and struggle to maintain a combination of national interest and local need. National aspiration is the main source to formulate the institutional design. On the other hand, they embedded local aspiration through ethnic and religious values to combine in national education. In keeping with the identities and personal communication, they tried to root the religious value and belief to educational form. Finally, this article amplifies the local condition in Pattani Muslim society. The development of Islamic education runs to the situation in extending ethnic, religious expression, and politic.
\end{abstract}

\section{INTRODUCTION}

Education is a necessity of every country and is a necessity to modernize people's lives (Putro, 2017; Widiatmaka, 2016; Yuristia, 2017). Education is also an important investment and has a strategic role for the realization of human resources to shape the mindset of citizens so they can develop themselves and build something new in the future (Widiatmaka, 2016).

Islamic religious education is a conscious and planned effort in preparing students to recognize, understand, and live up to the teachings of Islam (Rahman, 2012). Education in the perspective of Islam is a long process which functions are for teaching and helping students to acquire some aspects of knowledge according to Islamic parameters through the use of a well-designed curriculum (Bafadhol, 2016; Djaelani, 2013). Islamic education is a totality that can lead students to grow and develop as Islamic people in the family, community, nation, and state.

Education of a nation grows and develops in line with the nation's history. In subsequent developments, Islamic educational institutions such as madrasah and integrated Islamic schools start to emerge. This is in response to the pattern of education needed by the community. While in Southeast Asia, each country formed a pattern of Islamic education 
suitable to the aspirations of their respective communities.

Likewise, the Islamic education system in Pattani, Thailand, which is a country with a predominantly Buddhist majority, is updating the Islamic education system. The process of Islamic renewal in Pattani has a very long history. The position of Muslims as a minority religion leaves various turmoil and problems in the Islamic world. Muslim Pattani who inhabits Southern Thailand is predominantly consisting of Malay ethnic that has strong cultural roots. Since Islam entered Pattani, Islamic religious education began to be developed in mosques and traditional boarding houses. Thus, Pattani Malay Muslims have strong cultural and religious roots.

There is a transformation of Islamic education driven by the community (Wekke, Ashrori, \& Hamuddin, 2018). Madrasah does not merely teach religious subjects but also teaches exact sciences. Three typical educational institutions take place today (Medrano, 2007). Thai Islamic education not only maintains traditions that have lasted for so long, but it also demands a transformation to be developed following community needs (Joseph Chinyong Liow, 2010). Managing Islamic education does not mean that secular (non-Islamic) education is ignored. Precisely, with the existence of Islamic education, it will be an additional opportunity for the Thai Muslim community to participate in studies on a broader scale (Madmam, 2003).

When the Thai government took control of the Pattani region after the Anglo-Siam Agreement in 1909, the government began implementing various policies. Economic, social, educational, cultural, and religious policies caused turmoil between the Pattani Muslim community and the Thai government. The government's policy to reform Islamic education in Pattani is an effort to integrate Pattani Muslims as a minority part of Thailand. This article identifies the dynamics of Islamic education in Pattani from its historical roots to its development in the contemporary era.

\section{METHOD}

This study applied the qualitative approach. Researchers systematically describe the facts and characteristics regarding the portrait of the education of Thai Muslim communities. The validity of the data was determined using triangulation of sources. The sampling technique used in this study was the purposive sampling by determining the sample based on certain considerations. The consideration was based on the research subject related to the research problem. The data was obtained through in-depth interviews and observations. For triangulation of data, the observation was carried out twice, and interviews were conducted with different informants. There was also a directed discussion to verify the data of both research subjects and data collection techniques.

\section{RESULT AND DISCUSSION Minority and Ethnicity of Pattani Muslim}

Thailand is one of the countries located in Southeast Asia and is a member of the ASEAN (Association of South East Asia Nations). The government is a kingdom consisting of 76 provinces with a population of 57 million. The majority of Thailand's population is Buddhist and has dominated the country for 700 years. As the majority religion, Buddhism has the support of the State so that the culture of Buddhism develops rapidly in Thailand.

Meanwhile, Thailand Muslim lives in the southern part of Thailand. The Muslim population in southern Thailand is around 4 percent of the total population of Thailand. The largest numbers of Muslims are Malay and live in Thailand's three southernmost provinces; Pattani, Yala, and Narathiwat. Besides these three provinces, the Muslim community is also 
spread in several provinces such as Satun, Songkhla, Trang, Krabi, and Phuket. The Muslim population in southern Thailand is around 76 percent is in Pattani, Yala, and Narathiwat (Croissant, 2007).

In the $13^{\text {th }}$-century, Islam arrived in Pattani and became the majority religion in the region (Wayeekao, 2016). In the beginning, Pattani was a kingdom located in the south of Thailand with the Malay as a majority population. But in subsequent developments, the Pattani kingdom was later ruled by the Siamese kingdom. The Pattani Malay Kingdom was then divided into 4 provinces, namely Pattani, Yala, Narathiwat, and Satun. Siam's control over the Pattani region came into force after the Malay northern region was surrendered by the British colonial government to the Siamese kingdom in 1909. The surrender of the Pattani Malay kingdom to the Siamese kingdom was marked by the Anglo-Siam Agreement which brought the Pattani Malay kingdom under the control of the Siamese kingdom (Joll, 2010).

The Anglo-Siam Agreement, which recognized Siam's control over the Pattani Malay kingdom brought a policy that revoked the rights and dignity of Pattani Muslims. When the ultranationalist regime of Prime Minister Philbul Songkhram came to power in 1938, he adopted a policy of forcibly assimilating various minority cultures to be developed. Philbul immediately launched a campaign to wipe out Malay cultural identity for the sake of nationalism. This campaign attacks Malay Muslim identity on all fronts, including education, language, clothing, and religious practice (Croissant, 2007).

The policies of the Thailand government, which set the rules and assimilation process to the Pattani Muslim community gave rise to the spirit of nationalism to break away from the restraints of the Thai government. Relations between the Thai government and Muslim in Southern Thailand were filled with protracted mistrust, suspicion, and misunderstanding. Chronic upheaval between minority Muslims and the Thai government as a result of the combination of fragmented, weak, and insecure Islamic institutions and a disillusioned divided the Muslim community. As a result, resistance emerged, and the central government responded to it as the act of separatism until the martial law was imposed in the region (Joll, 2010).

Apart from the ethnoreligious conflict, Muslims in Southern Thailand, in the contemporary period, have experienced significant improvements in various fields, although it remains under pressure and discrimination from the Thai government. Thai Muslims are neither a new community nor a marginalized community. Therefore Muslims in Thailand today is an inseparable part of Thai society as a whole and remain a minority in various social and political fields (Jory, 2006).

\section{Institution of Pattani Islamic Education}

Islamic education in Pattani began since Islam came and settled in Pattani in the $15^{\text {th }}$-century. Basic education began in the Islamic community by studying the Quran. The Quran must be studied by every member of the community. Furthermore, the boarding school was built and became the most important educational institution in Pattani (Susanto, 2015). In further developments, Pattani later became the center of Islamic religious education in Southern Thailand and the Malay Peninsula at the time (Interview of Religious Education Teachers, 1/12/2018).

The education system of Islamic boarding schools, such as those found in Java, is also known by Thai people (Kesuma, 2017; Lamato, Sumarno, \& Umamah, 2017). The person who first introduced the education system was a student from Sunan Ampel in Java, Wan 
Husein. He was an influential Islamic figure in the development of Islam in Pattani. With the introduction of the boarding school system, Islamic teaching is no longer exclusively belong to the elite palace's royal people, but also belongs to the common people and commoners.

The Pattani Muslim Malay community chose the boarding school education system as a place of learning rather than attending formal education in government schools. During the reign of King Chulalongkorn (1868-1910) where the first formal education was implemented, the Pattani Malay Muslim community did not welcome the policy. In 1921, the government then passed a law requiring study at the elementary school up to fourth grade. Siamese was used as the instructional language in the learning process at school. The Pattani Muslim community considered this regulation to be a Siamese effort to erase their culture so that the Pattani people were reluctant to send their children to government schools.

It is known that a nation's education grows and develops in line with the nation's history. It also experienced by Pattani Muslims. The various turmoil and problems require Pattani Muslims to find the best way and act to address the development of the situation at that time.

The renewal of Islamic education in Pattani was inseparable from the role of a charismatic figure named Haji Sulong. This scholar and politician previously lived in the city of Mecca. In 1927, he returned to Pattani and founded the AlMaarif Al-Wathaniah Fathoni Modern Madrasah. This madrasah was the first school in Pattani that applied the graded learning, classroom system, and marching exercises. In further developments, the school was later closed by the Thai government because it was suspected to be the basis of Pattani Muslim to rebel against the Thai government.

The Pattani Muslim community rejects the education system adopted by the Thai government. They assume that there is a need to guide the national system with local traditions. Thai government policy that requires the use of the Thai language in the learning process makes the Pattani Muslim community send their children to boarding school education institutions rather than educational institutions provided by the government. For the Pattani Muslim community, the Thai government's policy towards the national education system was an attempt to erase the Malay Muslim identity in Pattani.

The efforts of the Thai government to implement a national education system were not responded well by the Pattani Muslim community. It made the government's efforts to integrate the Pattani Muslim community as part of the minority Thai people experiencing obstacles (interview of Islamic school teachers, Thailand 1/10/2018). Starting with this, the Thai government adopted a policy towards reforming the Islamic education system in Pattani. In 1958, the government attempted to eliminate the traditional boarding school education system by transforming into a modern boarding school or Islamic Private Education School (Interview with Fatoni University lecturer, Thailand, 2/7/2018).

As a realization of the government's efforts to transform traditional boarding school education institutions into modern boarding school or Islamic Private Schools, then in 1960, all boarding schools were registered. In 1961, the government began to intervene in the boarding school education system. Government policy to include semisecular education in the boarding school, change the use of Malay into Thai as the instructional language, and translate books into Thai is part of the government's interference in the boarding school education system. This effort was carried out to improve the quality of boarding school education (Principal of Private Islamic Schools, interview 
3/9/2018). Along with quality assurance, there is also a transformation of boarding school traditions.

Thus, the government was trying to reform the boarding school education system from a traditional boarding school to a modern boarding school or Islamic private school. In 1966 and onwards, traditional boarding schools followed the educational system renewal in Thailand although some others still maintained the traditional boarding school system (Principal of Private Islamic Schools, interview 2/12/2018). Until now, there are two features of Islamic educational institutions, namely: traditional and modern educational institutions (Private Schools of Islamic Education).

The Thai government's policy towards the Pattani Muslim community through education is an effort to integrate the Pattani Muslim community as part of a minority in Thailand. Government efforts to instill national awareness for the Pattani people are carried out through the Siamization, National Integration, and Socio-cultural Assimilation programs. To realize this goal, the steps taken by the Thai government are through education policies towards Islamic education in Pattani.

\section{Thailand National Education Policy and the Future of Islamic Education}

The implementation of Islamic education in Pattani was transformed from Mosques, traditional boarding school, madrasah (schools), to modern boarding school (Islamic Private Schools). At the beginning of Islam in Pattani, the mosques were used as religious education institutions. The learning conducted at the mosque focused on teaching the Quran, studying the Jawi books, learning the Berzanji, learning to become the Imam of prayers, and praying in congregation.

In subsequent developments, a traditional boarding school was established in Pattani, a pesantren boarding school. The learning system in traditional boarding school used the talaqi system (learning religious knowledge directly from the teacher). But in further development, the Thai government, through its policy, transformed the Islamic boarding school into Islamic Private Schools or modern boarding schools. Thai government policy to reform the Islamic education system impacts the change in the curriculum of the boarding school, which is the hallmark of Islamic education.

Islamic Private Schools or modern boarding school become formal Islamic education institutions in Pattani are still ongoing today. The education system takes place classically and receives regular government assistance. The curriculum used is an integrated curriculum between religious and general education. Integration between religious and general fields in the curriculum lies in the balance of religious and general subjects. In the technical aspect, realization in schools is carried out separately between religious and general education. For example, the religious learning process is carried out in the morning, while general lessons are held in the afternoon.

Thailand government policy to reform the Islamic education system is only to channel political desires so that Malay Muslim students learn religious and general education by integrating the understanding of nationalism and culture of Buddhism so that national and state awareness arises (Teacher Interview, 12/10/2018). The government's policy through education is to integrate the Pattani Malay Muslim community as a Muslim minority part of Thailand. Thus, the Pattani Malay Muslim extremism that triggers the disintegration of the nation can be eliminated.

The acts of the Thai Muslim community are perceived as an attempt to 
promote separatism. This built-up stigma (Jelonek, 2012) that makes Thai people not free to express their opinions. They are even labeled as terrorists (Croissant \& Barlow, 2007). Muslim communities, on several occasions get the same stigma as in Xinjiang (Warikoo, 2000). It is caused by an information gap between one another. The existence of a gap between government administration and the community will cause information gaps to occur (Ikelegbe, 2005).

The process of Islamic education, introduced by Haji Sulong and Ismail Lutfi (Joseph Chinyong Liow, 2010) became a separate model. There is integration between the national system and environmental aspirations (Aree, 2016). Although there is a perception that the Pattani people are seen as fighting for ethnicity (Harish, 2006), it's just that they are trying to provide a place for local needs for formal education. The efforts are made to integrate local aspirations with national education. Education management is related to personal ability to manage the course of the educational process and also institutional management (Wekke, Siami, \& Nuryantika, 2016).

There is an education modernization that began twenty years ago (Provencher, 1989). Although in the development of modernization, there are aspects of development that become its constraints (Scupin, 1989). Likewise, amid development efforts, there are challenges of violence and negative views (Porath, 2014). The development of Islamic education becomes a means to negotiate between identities (J.C Liow, 2005). Even from the beginning, there have been developments that were preceded by mutual suspicion as well as challenges (Yusuf, 1999). Global Islamic education is a blend of tradition and modernization (Wekke, 2015). This article shows that Thailand's Pattani Islamic education is undergoing both institutional and management transformation. Likewise, there is integration between national interests and environmental aspirations related to ethnic and religious needs.

\section{CONCLUSION}

The Islamic education system in Pattani metamorphoses from mosques, traditional boarding school, madrasah (schools), to modern boarding school or Islamic Private Schools. This process is inseparable from the intervention of the Thai government on the Islamic education system. The boarding school education system as the hallmark of Islamic education for the Pattani Muslim community is not only a place to gain religious knowledge but also as a place to affirm Malay Muslim identity.

Islamic educational institutions that still exist today are Islamic Private Schools or modern boarding school. Modern boarding schools are the result of government policies to transform the traditional boarding school, which at the beginning of the learning process emphasize subjects that are religious and oriented to the aspect of ukhrawi (afterlife). After the renewal of education from traditional boarding school to a modern boarding school, the education system takes place classically.

The government's policy to reform Islamic education in Pattani has an impact on the application of the education curriculum. The use of an integrated curriculum between religious education and general education has made the identity of the boarding school as a purely religious Islamic educational institution fading. The government's policy to reform the Islamic education system is only part of political efforts without regard to the quality to be achieved. Government policy through education is an effort to integrate the Pattani Malay Muslim community as part of Thailand.

\section{REFERENCES}

Aree, S. (2016). Integrated Islamic Education in Southern Thailand and Northern Malaysia: Reforms and 
Challenges. Journal of Human Rights and Peace Studies, 2(2), 75106.

Bafadhol, I. (2016). Pendidikan Agama Islam (PAI) di Islamic Boarding School. Jurnal Edukasi Islami Jurnal Pendidikan Islam, 05, 1371-1390.

Croissant, A. (2007). Muslim Insurgency, Political Violence, and Democracy in Thailand. Terrorism and Political Violence, 19, 1-18.

Croissant, A., \& Barlow, D. (2007). Following The Money Trail: Terrorist Financing and Government Responses in Southeast Asia. Studies in Conflict \& Terrorism, 30(2), 131156.

Djaelani, S. (2013). Peran Pendidikan Agama Islam dalam Keluarga dan Masyarakat. Jurnal Ilmiah WIDYA, 1(2), 100-105.

Harish, S. P. (2006). Ethnic or Religious Cleavage? Investigating The Nature of The Conflict in Southern Thailand. Contemporary Southeast Asia, 48-69.

Ikelegbe, A. (2005). The Construction of A Leviathan: State Building, Identity Formation and Political Stability In Nigeria. The Crisis of The State and Regionalism in West Africa, 71-92.

Jelonek, A. W. (2012). The Dynamics of Ethno-religious Separatism in Southern Thailand. Księgarnia Akademicka, (20/1), 135-154.

Joll, C. M. (2010). Religion and Conflict in Southern Thailand: Beyond Rounding Up the Usual Suspect. Contemporary South East Asia, 32(2).

Jory, P. (2006). Religious Labelling From Patani Malayu To Thai Muslim. Jurnal ISIM, 18(autumn).

Kesuma, G. C. (2017). Refleksi Model Pendidikan Pesantren dan Tantangannya Masa Kini. Tadris: Jurnal Keguruan Dan Ilmu Tarbiyah, 02(1), 67-79. https://doi.org/10.24042/tadris.v2i1.1
740

Lamato, H., Sumarno, S., \& Umamah, N. (2017). The Role Of Haji Sulong In Fighting Special Autonomy For Patani Southern Thailand (19471954). Jurnal Historica, 1(1), 47-64.

Liow, J.C. (2005). Islamic Education in Thailand: Negotiating Islam, Identity and Modernity. Southeast Asia Education Survey, 121-149.

Liow, Joseph Chinyong. (2010). Religious Education and Reformist Islam in Thailand's Southern Border Provinces: The Roles of Haji Sulong Abdul Kadir and Ismail Lutfi Japakiya. Journal of Islamic Studies, 2l(1), 29-58. https://doi.org/10.1093/jis/etp026

Madmam, H. (2003). Secular Education, Values and Development in The Context of Islam in Thailand: An Outlook on Muslim Attitudes Toward Thai Educational Policy. Asian Interfaith Dialogue. Perspectives on Religion, Education and Social Cohesion, 66-77.

Medrano, A. D. (2007). Islamic Education in Southern Thailand. Islam in Southeast Asia, 7(2).

Porath, N. (2014). Muslim Schools (Pondok) in the South of Thailand: Balancing Piety on a Tightrope of National Civility, Prejudice and Violence. South East Asia Research, 22(3), 303-319.

Provencher, R. (1989). Islam, Modernisation And Nationalism: Traditional Resolution of An Apparent Dilemma. Aspects of Development: Islamic Education in Thailand and Malaysia, Institut Bahasa Kesusasteraan Dan Kebudayan Melayu, Universiti Kebangsaan Malaysia, Bangi, 1546.

Putro, T. S. (2017). The Learning Concept of Pondok Songserm Wittaya Takamcham Sub-Distrik Nong Chik Regency, Southern Thailand. Jurnal 
Pendidikan Islam, 6(1).

Rahman, H. A. (2012). Pendidikan Agama Islam dan Pendidikan Islam Tinjauan Epistemologi dan IsiMateri. Eksis Riset, 8(1), 2053-2059.

Scupin, R. (1989). Aspects of Development: Islamic Education in Thailand and Malaysia. Institut Bahasa, Kesusasteraan Dan Kebudayaan Melayu, Universiti Kebangsaan Malaysia, 7.

Susanto, P. (2015). Perbandingan Pendidikan Islam. Jurnal Pendidikan Islam, IV(1), 71-93.

Warikoo, K. (2000). Muslim Separatism in Xinjiang. Himalayan and Central Asian Studies, 4(3/4), 32.

Wayeekao, N. (2016). Berislam dan Bernegara bagi Muslim Patani : Perspektif Politik Profetik. Jurnal Agama Dan Hak Azazi Manusia, 5(2), 352-406.

Wekke, I. S. (2015). Antara Tradisionalisme dan Kemodernan: Pembelajaran Bahasa Arab di Minoritas Muslim Papua Barat. Jurnal Peradaban Islam Tsaqafah, 11(2), 313-332.

Wekke, I. S., Ashrori, M., \& Hamuddin, B. (2018). Institutional Transformation of Madrasa of Muslim Minority in Thailand. Jurnal Pendidikan Islam, 4(1), 15-26. https://doi.org/10.15575/jpi.v4i1.196 1

Wekke, I. S., Siami, S., \& Nuryantika, N. (2016). Kepemimpinan Sekolah Islam Terpadu di Minoritas Muslim Papua Barat. Akademika: Jurnal Keagamaan Dan Pendidikan, 12(2), 3-9.

Widiatmaka, P. (2016). Kendala Pendidikan Kewarganegaraan dalam Membangun Karakter Peserta Didik di dalam Proses Pembelajaran. Jurnal Civics, 13(2), 188-198.
Yuristia, A. (2017). Keterkaitan Pendidikan, Perubahan Sosial Budaya, Modernisasi dan Pembangunan. Ijtimaiyah, 1(1), 117.

Yusuf, I. (1999). Aspects of Islam in Thailand Today. ISIM Newsletter, $3(1)$. 